\title{
Optimizing the role of informal learning in the perspective of Islamic education during the Covid-19 pandemic
}

\author{
Annisa Arsya Wardani1* (1) https://orcid.org/0000-0002-2080-5565 \\ Toto Suharto $^{2}$ (i) https://orcid.org/0000-0001-8351-9067 \\ ${ }^{1}$ Islamic Education, Postgraduate IAIN Surakarta, Indonesia \\ 2Islamic Education, Postgraduate IAIN Surakarta, Indonesia
}

\begin{abstract}
Online learning is chosen during the Covid-19 pandemic. The problem that occurs is teachers as educators cannot directly supervise the development of students, so they need help from the informal educational institution.. In this context, parents take the role of facilitators during online learning. Not only limited to the educational function of parents, but it also has many roles that can be optimized so that children can grow and develop properly. The purpose of this study is toportray the role of families, especially parents in optimizing their role when online learning is present during the Covid 19 pandemic. The method used in this research was qualitative descriptive. This study used the data triangulation method as a technique to measurethe validity of the data. The analysis technique used in this research was interactive model analysis. The interactive analysis included data reduction, data presentation, and conclusions. The main results of this study were parents, apart from being an educational institution, whoalso took a role of being shaping children's character and personality that is to stimulate children's linguistic intelligence. Parents can also stimulate children's intrapersonal intelligence by adapting to behavior that is appropriate to the local cultural environment. The contribution of this research includes the function of parents which is not only maximizing scientific education but also deepening the internalization of spiritual and religious values in children, as well as building good communication is needed to optimize the role of parents to children.
\end{abstract}

\section{ARTICLE INFO \\ Keywords:}

Covid-19 pandemic;

informal learning; online

learning; parental function

\section{Article History:}

Received: 01 March 2021

Revised: 06 April 2021

Accepted: 06 April 2021

Published: 05 May 2021

How to Cite in APA Style:

Wardani, A. A. \& Suharto, T. (2021). Optimizing the role of informal learning in the perspective of Islamic education during the Covid-19 pandemic. Journal of Educational Management and Instruction, 1(1), 28-39

\section{Introduction}

The Covid-19 pandemic has caused various sectors to experience crises. One of the sectors affected is the education sector. Quoted from BBC Indonesia (13/7) UNESCO data shows that in April, 1.6 billion students were dismissed from schools and universities due to measures to curb the spread of Covid-19. This figure is about $90 \%$ of the total student population in the world. This is done in an effort to protect students from being infected with Covid-19, a transmission that is so fast and invisible, so this virus is very dangerous. Even though the school was closed, learning was still carried out by means of distance learning which was carried out in each house.

In education, the learning process is essential because these activities require planning and supporting materials in order to create ideal learning. Learning has the meaning of interaction activities carried out by teachers and students who are expected to be able to achieve educational goals. According to Pane \& Darwis Dasopang in (Putria, 2020) regarding the learning process, according to them the learning process is a system involving a single component that is interrelated and interacted with each 
other to achieve an optimal expected result in accordance with predetermined goals.Distance learning carried out in each home was chosen as the most appropriate solution because teachers and students do not need to do face-to-face learning so that it can prevent the spread of the Covid-19 virus from spreading.

The Minister of Education and Culture said the condition of the COVID-19 Pandemic did not allow teaching and learning activities to take place normally. There are hundreds of thousands of schools closed to prevent spread, around 68 million students are carrying out learning activities from home, and around four million teachers conducting remote teaching activities (Kemendikbud, 2020).The implementation of online learning is to anticipate that teacher relatives cannot face to face with students and to face sudden problems such as the COVID-19 pandemic which has shocked the whole world, causing all human activities to wake up (Pratiwi, 2020). Distance learning can take place if electronic media such as gaway or laptop are available and connected to the internet network. This requires teachers and students to master technology to facilitate distance learning. Some of the conveniences in distance learning are unlimited space in the classroom, because students can study in their room, on the home page or even in the open. Then the distance and time are more flexible, this makes it easier for students who have long distances from school because learning can be done at home without traveling (Baidi et al., 2020).

The distance learning that students do is mostly guided by the family, who is a substitute for the teacher when they are at home. What is meant by family in the context of the nuclear family is husband-wife or father-mother as the main figure who synergizes in realizing the educational goals of their children. Meanwhile, in the context of a large family, this is where the importance of family development is very important in education. The essence of this informal education generally includes family formation, especially the education of children. This finds its vitality because of the very strong motivation that the ultimate goal of family fostering is to save the family from adversity in the afterlife and the formation of the perfect child's personality (Yakub, 2020).

In Law Number 2 of 1989 concerning the National Education system Article 10 paragraph (4) states that: family education is part of the out-of-school education pathway which is held in the family and provides religious beliefs, cultural values, norms, and skills. Likewise, in line with the formal juridical Law of the Republic of Indonesia Number 20 of 2003 concerning the National Education System Chapter I Article 1 is stated; Education is a conscious and planned effort to create an atmosphere of learning and the learning process so that students actively develop their potential for have religious spiritual strength, self-control, personality, intelligence, noble character, and skills needed by him, society, nation, and state (Hasbullah, 2013).

The family is the first environment to get education so that education in this family is often called natural education that is inherent in every household. Education in this early phase is the basis which is ultimately very influential and decisive for further education. Education carried out in a family environment is guidance and assistance by parents to their children who are given consciously in accordance with their physical (physical) and spiritual (psychic) development towards perfect maturity.

This rule is established by nature, because they are destined to be the parents of the child who is born. In simple terms, the obligation of parents is only to develop what is primordially present in the child, namely the nature of his own goodness in accordance with his nature. But on the other hand, parents also have a role to determine and bear the burden of the main responsibility if a child deviates from his nature and potential goodness so that he becomes a human with low quality characteristics. This is one of the meanings of a well-known hadith which states that every child is born in nature (nature, holiness), then the mother and father may make him deviate from that fitrah (Ma'sum, 2015). 
Online learning has both advantages and disadvantages, one of the drawbacks is that teachers cannot maximize intensive coaching and improve student behavior and student understanding of the material factually. Students' understanding depends on the absorption of each individual by lighting when learning is done online. Parents play the role of facilitators and explorers. At the elementary school level, parental assistance is needed when the online learning process takes place and outside of online learning because students and their parents are almost twenty-four hours. In the view of Islamic education, learning is not only from the results of its evaluation but also the internalization of the values of Islamic teachings in an individual. According to (Ma'sum, 2015). Education in Islam gets a very high place and rank, because through education people can gain knowledge, and with knowledgepeople can know their God, reach ma'rifatullah. Someone's worship will be hampered if it is not accompanied by knowledge. Likewise, the level of a person, in addition to faith, is also very much determined by the quality of one's knowledge (wisdom). Therefore, this research focuses onon the optimization of the function of informal education, especially for parents during the COVID-19 pandemic.Drawing on a qualitative research, this study's results contribute add insight into the development of informal education especially parents related to online learning during the Covid-19 pandemic.

\section{Informal Education Concept}

Education for human life is an absolute necessity that must be fulfilled throughout life. Unlike formal education, informal education rarely gets attention, but this early education is the most important, namely education in the family. Informal education is family education in which the family functions as the first and foremost educational institution. According to Ki Hajar Dewantara, a family is a collection of individuals who have a sense of unconditional devotion, for the benefit of all individuals who take shelter in it. That is the importance of the family of human life for individuals and groups of people.

Ki Hajar Dewantara, an Indonesian education figure, also stated that the family realm for each person (child) is the realm of early education. For the first time, parents (father and mother) serve as guides (teachers), as teachers, as educators, mentors and as the primary education for children. So it is not an exaggeration to refer to the opinion of experts on the concept of family education. It is not just an action (process), but it is present in practice and implementation, which is carried out by parents with educational values in the family (Jailani, 2014).

Livingstone in (Sudiapermana, 2003) defines informal education as any activity that involves the pursuit of understanding, knowledge, or skills that occur outside the institutional curriculum provided by educational programs, courses or workshops. Informal learning can occur in any context outside the institutional curriculum. It is distinguished from daily perceptions and general socialization by identifying the individual's self-awareness of activities as meaningful learning. The basic things of informal education (objectives, content, method and process of acquisition, duration, evaluation of results and applications) are determined by the individuals and groups who choose to be involved in it, without the presence of an instructor who has institutional authority. In many academic studies, indicators of informal education are always related to independent learning and the absence of certain parties who deliberately build interactions and intervene.

Between family and education, there are two things that cannot be separated because education is in the family and when parents carry out their duties and obligations to educate children at the same time the child gets and inspires education from parents. The presence of the family in educational discourse is a necessity that cannot be avoided, this departs from the basic awareness that the family is the first social group for humans. In the family, for the first time, humans learn to communicate 
and interact with other humans. Besides, humans also try to get to know themselves, and then try to construct their life in the family. Family becomes the initial reference for humans in general, to form the paradigm of their life. This is a process that is naturally born as a complete unit in the dimensions of human life. Therefore, such an important social process is created for the first time in the circle to family, then this is the basis why the process of forming the human personality begins with family education (Labaso, 2018).

Basically family education is the first and foremost education for a child. Therefore, the obligation of parents to their children is not just members and fulfilling physical needs, but more importantly instilling religious values in children as early as possible, because the religious education they receive will greatly affect their religious experience after they grow up. In a family, parents are idol figures for their children, where every gesture and behavior of parents always get serious attention from children, even children are more likely to imitate the behavior of their parents.

\section{The role of parents}

The human tendency to imitate, through imitation, to mention exemplary is very important, meaning that in the teaching and learning process or family education. It is the attitude or behavior of parents that will be imitated by their children. Therefore, the role of parents is parenting, which is to educate children to do good in the form of words and deeds. Second is coaching, which is to give encouragement or stimulation to children to do good. Third, get used, which is trying to get children to do or say well as early as possible so that children always do it in everyday life. The fourth is nurturing, which is keeping children away from bad things that occur in the family and society. Finally, namely giving sanctions, giving sanctions and warning to children who commit violations so that the child does not repeat it (Arifin, 1997).

\section{Method}

\section{Research context and participants}

The method used in this research was a qualitative descriptive approach, descriptive research. Meanwhile, the source was taken from several scientific books published with the intention of being a reference source, and the data collection techniques in this research were literature study, interviews and observation (Yakub, 2020). Researchers in conducting interviews need to do directly between researchers and informants so that they can be more open in communicating in order to obtain clear and concrete data. According to Moleong in (Wahyu Nugroho, 2019) the sense of an interview is a conversation with a specific purpose. The conversation was carried out by two parties, namely the interviewer (interviewer) who asked the question and the interviewee (interviewee) who gave the answer to the question. Interviews were conducted with the parents of grade two of SDN 6 Wonogiri as research subjects. Selection of informants using homogeneous sampling technique aimed to focus the analysis on one problem, reduce variation, simplify analysis, or facilitate group interviews. Informants in the interview amounted to 20 people.

\section{Instrument and data collection}

According to Sugiyono in (Adhimah, 2020), research begins by taking notes, analyzing and then making conclusions. This study used non-participant observation techniques, because the researcher was not involved and only acts as an independent observer. Researchers in making observations used the five senses maximally so that they can animate the research object. This observation was divided into two parts, namely direct and indirect observation. The data source was the subject from which the data was obtained in this study (Nugroho, 2019). The data source wasto optimize the function of informal education during the pandemic. To obtain data and information 
related to the problems discussed in this study, various sources were used as follows: Primary data were from questionnaires and interviews with parents, guardians of students, while secondary data were from books and previous research This study used the data triangulation method as a technique to measure the validity of the data. According to Wirawan in (Adhimah, 2020) triangulation is a research approach that uses a combination of more than one strategy in one study to capture data / information. By collecting and comparing multiple data sets with each other, triangulation helps negate any threats to the validity and reliability of the data.

\section{Data analysis}

The analysis technique used in this research was interactive model analysis. The interactive analysis included data reduction, data presentation, and drawing conclusions. The research data that has been collected is then reduced. Huberman in (Listyaningsih, 2019) states "Data reduction is a form of analysis that sharpens, classifies, directs, removes unnecessary and organizes data in such a way that the final conclusions can be drawn and verified". After the data were reduced, the next step was to display the data. In qualitative research, data presentation can be done in the form of brief descriptions, charts, relationships between categories, flowcharts. According to Sugiyono in (Nugroho, 2019) the initial conclusions put forward are still temporary, and will change if no strong evidence is found to support it at the next data collection stage. But if the conclusions put forward at an early stage are supported by valid and consistent evidence when the researcher returns to the field of collecting data, then the conclusions put forward are credible conclusions.

\section{Results}

The purpose of this research is to examine how to optimize the function of parents as educational institutions outside of schools during the Covid 19 pandemic in the perspective of Islamic education. This research was conducted on the parents of the two grade students of SDN 6 Wonogiri.

Learning during a pandemic requires guidance and contributions from various parties, in addition to teachers as the main teachers, parents also have an educational function when learning is done online. The following are the results of a questionnaire that has been given an assessment by the parents of students who accompany their children to learn online:

Table 1.The results of a parent questionnaire during online learning during the Covid19 pandemic

\begin{tabular}{|c|c|c|c|c|c|c|}
\hline \multirow[b]{2}{*}{ No. } & \multirow[b]{2}{*}{ Statment } & \multicolumn{5}{|c|}{ Options } \\
\hline & & $\begin{array}{l}\mathrm{TD} \\
\mathrm{A}\end{array}$ & $\begin{array}{l}\mathrm{D} \\
\mathrm{A}\end{array}$ & DB & A & $\mathrm{TA}$ \\
\hline 1 & $\begin{array}{l}\text { I assist when learning online because it could be that my } \\
\text { child does not understand the learning material }\end{array}$ & 0 & 0 & 1 & 15 & 4 \\
\hline 2 & $\begin{array}{l}\text { I encourage them to study hard and be disciplined in } \\
\text { submitting assignments }\end{array}$ & 0 & 0 & 0 & 17 & 3 \\
\hline 3 & I invite you to worship regularly and pray on time & 0 & 0 & 0 & 12 & 8 \\
\hline 4 & I try to be a good example in both words and deeds & 0 & 0 & 0 & 13 & 7 \\
\hline 5 & $\begin{array}{l}\text { I invite to play when children feel bored with online } \\
\text { learning }\end{array}$ & 0 & 0 & 4 & 10 & 6 \\
\hline 6 & I try to build good communication with children & 0 & 0 & 0 & 14 & 6 \\
\hline 7 & $\begin{array}{l}\text { I believe the environment influences the development of } \\
\text { children's behavior and enthusiasm for learning }\end{array}$ & 0 & 0 & 0 & 18 & 2 \\
\hline 8 & I try to really love children & 0 & 0 & 0 & 15 & 5 \\
\hline 9 & I am responsible for the safety and development of & 0 & 0 & 0 & 10 & 10 \\
\hline
\end{tabular}




children
10 $\begin{aligned} & \text { I try to provide facilities and infrastructure for online } \\
& \text { learning }\end{aligned} \quad$\begin{tabular}{llllll}
0 & 0 & 2 & 10 & 8 \\
\hline
\end{tabular}

(Source: Questionnaire, 2021)

Online learning has two sides, namely constraints and convenience because this system is new in Indonesia. Online learning is an option during the Covid 19 pandemic because face-to-face is risky if it is still held. This learning is carried out by students learning at home through their respective gadgets and teachers providing material online. The learning is carried out in the respective student's house, so the parents become a companion during the online learning. Here the authors describe the results of the questionnaire along with the results of the interviews that have been conducted:

\section{Facilitating and accompanying online learning}

Learning at the elementary school level has many obstacles, one of which is confusion in using gadgets. This is where parents have a role as facilitators and assistants. Furthermore, this is expressed in an interview with one of the students' parents,"because using google classroom is a new thing, my child is confused, I even have to ask a neighbor to send my child's assignment and I inevitably have to learn to use this application because learning is done online". In columns 1, 2 and 8, it shows that more than $60 \%$ agree that parents act as facilitators and assistants during online learning. This shows the awareness and responsibility that parents have to educate their children and try to discipline children so that they can achieve achievements the good one.

\section{Equipping children with religious understanding}

Apart from achieving in academics, parents are also responsible for providing religious knowledge. Worship can discipline children in practicing the awareness of good behavior towards God and also fellow creatures. Columns 3 and 4 show that more than $70 \%$ agree that parents play a role in raising children's awareness to worship

Independently, this is expressed by the parents of the students "in my personal opinion education about religion is a balance for the life of each individual. Therefore, I try to get children to worship, even though it has not been perfectyet, but I try to get use to it every day"

\section{Building a good relationship between parents and children}

Building good bonds between families is needed when educating children because children will imitate and practice what they experience. The existence of the intensity of communication maintained is a medium for recreation because when expressing feelings and thoughts will make the heart relax. On the other hand, during the pandemic, they cannot travel and meet people freely, so many people feel bored and tired of their routines. This saturation can go to both parents and children. Parents need to build good relationships, one of which is playing with children when they are free. This is addressed in tables no. 5 and 6 that more than $60 \%$ agree to play with children and build good communication is necessary. and based on the parents' explanation as follows "when children are in a bad mood they are told to learn like to be fussy. Sometimes if they are too hard they force them to do it. Due to the school assignment, the child will get sick easily. So, as a parent, I don't force the child too much but try to communicate well about the situation in this pandemic so that the child also understands why he should stay at home too long and keep learning even though it is online. 


\section{Supporting the growth and development of children}

Based on the questionnaire of the majority of parents who try to facilitate learning optimally,in order to try to provide the best for their children, parents feel responsible when their children are left behind in learning. Based on table no. 7, 8, 9 and 10 , parents agree to play a role in supporting the development of their children starting from being aware of the role of parents and the environment, child safety and providing learning facilities. More than $60 \%$ of parents agree that the facilities are in learning, but due to economic limitations some parents cannot maximize the provision of facilities for their children. This was stated by the student's parents as follows "because the child is learning online, I accompany him and use my cell phone. I feel that it is not time for children to hold their own gadgets, they still need supervision. For me, providing gadgets is not a burden, but for some other parents, it can be an obstacle both from gadgets, internet packages and the use of online learning applications. "

\section{Discussion}

One of the roles of family education in shaping children's character and personality is to stimulate children's linguistic intelligence by teaching children how to speak the language in daily interactions. Parents can stimulate the child's intrapersonal intelligence by refraining from behavior that is in accordance with the local cultural environment, such as children's habit in respecting their own work regardless of its form, and parents exemplify exemplary behavior by not comparing the children's work with the work of relatives or friends.

The role of parents in education is not limited by time or material. When children are teenagers or adults, parents still have a very important role because informal education does not only teach children about speaking, singing, dancing, or their own interests, but also teaches skills related to social life. Especially with regard to moral values and commendable morals, so that the role of parents is always needed in informal education at any time (Laili, 2020; Nugroho et al., 2021). Distance learning in the era of the Covid-19 pandemic carried out by students is mostly guided by their families, parents become substitutes for teachers when they are at home. What is meant by family in the context of the nuclear family is husband-wife or father-mother as the main figure who synergizes in realizing the educational goals of their children. Because students during the pandemic are always with their families, informal education becomes an educational institution whose role greatly affects the learning process and outcomes (Ubabuddin, 2018). Then the optimization of the role of informal education is needed, namely:

\section{Optimizing Educational Functions}

The family as an element of the central level of education is the first educational environment for children. In this position, it is normal for the daily life of the family, at certain times an educational situation is lived up by the child and is directed at actions that are following the goals of education(Zainuri, 2018). Different from education in general which is built based on human concepts in the basis of their respective philosophies, education in Islam is built by departing from the concept of humans in the basis of Islam. In the view of Islam, humans are "khalifatullah" on earth. Therefore, humans are equipped with all their potential as provisions for their caliphate. This potential is manifested in two forms, namely tending to positive things and those that tend to negative things (Achmad, 2020). Because learning is carried out with an online learning system, families need to accompany children during the learning process. Parental participation can effectively improve children's academic achievement, improve children's character, increase children's adaptability in school, and increase children's graduation rates. Therefore, parents should actively participate in monitoring their child's learning and avoid being indifferent to their children's 
activities at home. By not comparing and forcing children when learning online, children will be able to learn at home optimally and be fun. Education is not only limited to materials in books, but also emotional education and moral education can also be maximized because the child is at home with parents. In this case, parents should not add to the burden by asking their children to get perfect scores. During the pandemic, the curriculum objectives are not the only goal, but it is hoped that children can be involved in meaningful learning related to life skills. Children can still get inspiration from useful learning in everyday life and carry out activities. The method applied was by using the Uswatun Hasanah's method, which exemplifies good behavior for children in a contextual manner. Applying the method of habituation and advice to understand children about learning is also applied. Parents can create various learning opportunities by organizing children's activities. Children participate in activities agreed upon between parents and children.

\section{Optimizing children's socialization functions.}

The family's duty in carrying out this function is how the family prepares children to become good members of society. Families socialize to their children about values, norms, and ways to communicate with others, teach about good and bad things as well as wrong and right things (Herawati et al., 2020). Families introduce children to the outside world by learning discipline, getting to know culture and norms through interaction within the family so that they are able to play a role in society(Chandra \& Pattiruhu, 2019). Even though being at home, communication between family members needs to be maintained properly. Most children who are at home during a pandemic Covid-19 easily feel boredom, so families need to maintain good communication with children both during learning time or outside online learning hours. With good communication, it will develop children's social skills. Parents should not yell at children when they make mistakes but parents must appreciate the children'sefforts that eventually will form children's personalities; confident, optimistic and courageous. Communicating with children may be simple, and it seems easy, but the facts prove that this has great benefits for children's growth and development. From an early age, it is necessary to establish positive communication with children so that it can help foster children's self-confidence, build children's self-esteem. This will make the children feel more valuable, build a positive self-concept of children, and help children build relationships with other people around them. Good communication can also make good relationship between children and parents. On the other hand, bad communication will cause children to disrespect their parents, and there will be frequent quarrels between children and parents, which make children feel worthless. When children face conflict, parents are expected to be the first place to complain. When children get used to expressing opinions, they feel free, open up, and become more honest people in society.

\section{Optimizing Protection Functions}

The duty of the family in this case is to protect children from bad actions so that family members feel protected andsafe. The protection function means that the family is a place of shelter or refuge for all its members and a place to foster a sense of security and warmth. The family protects every member from bad actions so that family members feel comfortable and safe (Herawati et al., 2020). This protection function is to protect children not only physically, but also psychologically. Physically the protection function is intended for family to maintain biological growth so that it can carry out tasks proportionately (Nartiningrum \& Nugroho, 2020; Zuhlaini, 2019) According to Al-Ghazali in (Asfiyah \& Ilham, 2019), he pays serious attention to the association of children, because an association has a dominant influence on children's development, and the main thing of education is to protect and protect children from bad associations. 
When learning in the era of the Covid-19 pandemic, families continue to be at home in an intense time. This can increase boredom for both children and parents. Therefore, families need to increase vigilance to always protect children so that they are able to avoid violence when learning online when at home or the wrong association of children when playing with their friends. Supervision also needs to be done when using gadgets because children are still minors and their curiosity is high because the proliferation of untrue and uneducated content can form bad characters in children indirectly(Wahyuningsih\& Baidi, 2021).

\section{Optimizing Religious Functions}

A religious function encourages the development of the family and all its members into religious beings who are full of faith and devotion to God Almighty (Salusi, 2017). Education in Islam, especially children's education, teaches parents how important to be a figure in shaping the child's personality so that the child grows up as a figure who educates and raises him. It is time for the Muslim community in particular to re-read religious literature, both the Qur'an, Hadith, and other literatures that specifically discuss the procedures for educating children in an Islamic perspective concerning the successful growth and development of children into ideal personalities (Asfiyah \& Ilham, 2019).Fostering obedience to worship in children also starts from within the family by guiding and teaching or training children with religious teachings such as shahada, prayer, ablution, prayers, reading the Al-Qur'an. Pronouncing dhikr and commendable morals, such as being grateful when receiving gifts, being honest, building brotherhood with others, and keeping away from actions forbidden by Allah (Wijayanti, 2019).

When a pandemic occurs, activities that can relieve stress are needed so that it is necessary to worship diligently and solemnly. The impact of education from this realization is the growth and development of students and their development towards maturity in a family environment that is built on a foundation of piety to Allah, the spirit of upholding His laws, and making His shari'a a decision in all aspects of life. In such an atmosphere, students learn and even imitate. From the description above, it can be explained that family education means a process of assisting with good practice continuously (continuously), to obtain good and noble morals. Parents need to provide encouragement and good advice to children. So that children get motivation to do good and immediately return to the right path in accordance with religious guidance if they make mistakes. Parents try to guide the practice of religion in the family environment. For example, getting used to always praying, saying greetings, kissing parents' hands, praying at the beginning of time, doing good to relatives and neighbors, and habituating other good attitudes and deeds taught by religion.

\section{Optimizing Recreational Functions}

Creating a home climate that is warm, friendly, free, relaxed, peaceful, joyful, so that all family members feel at home (Wijayanti, 2019). Affection function means family as a place of contact and discussion between family members, a good communicative place between people, parents and children by providing intimacy, warmth, through words, gestures, expressions, actions (Dirgayunita et al., 2020).

This is useful for building bonds between children and parents in the future. When parents ignore their children, it is not impossible if one day after the child grows up they will leave, neglect, and ignore the condition of their parents. This is nothing but the result of learning his parents given him since he has been still in family care. It cannot be said to be an act of retaliation, but the behavior of the child gets from the experience that the child receives from his parents and then internalizes it so that it becomes an exclusive personality, ignoring anything but himself (Asfiyah \& Ilham, 2019). The family in this recreational function does not have to always go away, to a 
recreation area, but the important thing is how to create a pleasant atmosphere in the family so that it can be done at home by watching TV together, telling stories about each other's experiences, and so on. Not only parents or adults can experience boredom because of daily routine, but also children do. The daily routine of children can also cause boredom, which willof course have a negative effect on children. Both parents and children alike, all need a moment to take a break from routine daily activities.Having happy moments together is an invaluable moment. Although it may be done in a short time, it is of course also important for children. Gathering with family, although brief, will not only increase the sense of togetherness, but also be useful as a means of learning to socialize for children.

\section{Optimizing the Feeling Function}

Affection illustrates that the family must be a place to create an atmosphere of love and affection in family life (Herawati et al., 2020). If the affective function in a family is good or it can be said that the family is harmonious, the emotional intelligence of the child will be smarter. It can be concluded that the affective function of the family in a family is very important to improve emotional intelligence (Purba et al., 2019). All of these efforts reflect the care, affection and care of parents towards their children, which will undoubtedly be memorable for the child's life. This means that children as biological beings are considered to have serious care from their parents in order to grow and develop according to their nature. Some parents think that to correct a child's bad attitude, they must be followed by harsh ways such as punishing, saying loudly. This method will not work, on the contrary, it will create a grudge against the child (Ubabuddin, 2018). In online learning, affection is needed and very important, in many cases of violence against children due to boredom from parents. Data collected from the Online Information System for the Protection of Women and Children (SIMFONI PPA) from January 1, 2020 to September 23, 2020, shows that there were 5,697 cases of violence against children (KtA) in Indonesia with 6,315 victims. "The information circulating even states that the majority of these children experience violence due to the annoyance of their parents in accompanying online learning at home," said IPB lecturer from the Department of Family and Consumer Sciences (IKK) Dr. 2020). It is an obligation that parents educate children with love, to avoid violence against children. When online learning, it requires an understanding from parents, and when experiencing boredom as much as possible take a break to relax, so not to force the children too much to get the perfect score. Starting from understanding the character of children, building good communication and loving each other between families, we continue to strive. With full love and good communication, children will understand and respect their parents (Kompas, 2020).

One of the children's rights that should not be neglected is to get love and affection in the family. Parents are expected to be able to provide love and affection and warmth and to provide security for their children. Parents play an important role in fulfilling these children's rights. In addition to providing love and comfort for children, parents must also instill a good personality, discipline, and encourage children to grow up to be brave in facing life. The love given by parents to their children is also carried out appropriately, because if it is given excessively it can have a negative impact on the child's growth and development and mental development. That way parents must continue to give love in a reasonable portion. As we know, excessive affection for children will have a negative impact on the child's mental and development. Therefore,giving love wisely is something that needs attention. Every child has the right to be cared and guided with love in the coaching process so that the child can grow optimally according to their interests, talents and potential as well as socially. In his statement, there are often opposite actions, even acts of violence are carried out by the closest people (parents or family, caregivers) and teachers at school. The impact of 
these actions can be long-term psychoogy that affects the child's personality. There are many actions that are well-intentioned but are not carried out in an appropriate manner so that inadvertently it has a negative influence on the spirit of child development. Therefore, the concept of increasing welfare in child protection must prioritize in the best interests of the child over other interests, including the interests of parents or family.

\section{Conclusion}

The purpose of this study is to portray the role of families, especially parents that are able to optimize their role when online learning is present during the Covid 19 pandemic, so that it is expected to produce good and virtuous output. The method of this research used a qualitative descriptive approach, descriptive research. This study used the data triangulation method as a technique to measurethe validity of the data. The analysis technique used in this research was interactive model analysis. The interactive analysis included data reduction, data presentation, and conclusions. The results of this study indicate that families, especially parents, can maximize their role in online learning. Family can do the followings; Facilitating and accompanying online learning, Equipping children with religious understanding, Building a good relationship between parents and children, Supporting the growth and development of children. This study's results contribute to add insight into the development of informal education especially parents related to online learning during the Covid-19 pandemic. The limitation or weakness in research lies in the research process. Researchers realize that in a study there must be many obstacles. One of the obstacles in this study is the place and time of research. Because the Covid-19 pandemic limits face-to-face and territorial restrictions, researchers cannot observe intensively. Therefore, the suggestion for the next researchers is to be able to conduct intensive observations on the learning process by parents who have tried to increase their role and the researcher can make observations at students' homes.

\section{References}

Achmad, W. (2020). Peran dan tantangan Pendidikan Agama Islam di era pandemi covid 19 pada lingkungan keluarga. JIE: Journal of Informal Education. 5(2), 169182.

Adhimah, S. (2020). Peran orang tua dalam menghilangkan rasa canggung anak usia dini (studi kasus di desa Karangbong RT. 06 RW. 02 Gedangan-Sidoarjo). Jurnal Pendidikan Anak, 9(1), 57-62. https://doi.org/10.21831/jpa.v9i1.31618

Arifin, M. (1997). Hubungan timbal balik pendidikan di lingkungan sekolah dan keluarga (1st ed.). Bulan Bintang.

Asfiyah, W., \& Ilham, L. (2019). Urgensi pendidikan keluarga dalam perspektif hadist dan psikologi perkembangan. Hisbah : Jurnal Bimbingan dan Konseling. 16(1), 120.

Baidi, Heldy Ramadhan Putra, P., \& Junaidah. (2020). The effect of leadership style and work motivation on work productivity for teachers in all state junior high schools of surakarta. Universal Journal of Educational Research, 8(3D), 67-72. https://doi.org/10.13189/ujer.2020.081710

Chandra, I., \& Pattiruhu, S. (2019). Fungsi afektif keluarga dan fungsi sosialisasi keluarga dengan perilaku seksual remaja. E-Journal Keperawatan, 7(2), 1-9.

Dirgayunita, A., Tinggi, S., Islam, A., Probolinggo, M., \& Islam, H. (2020). Pendidikan keluarga syariah menurut hukum islam dan psikologi. Jurnal Imtiyaz, 4(2), 163174.

Hasbullah. (2013). Dasar-dasar pendidikan. PT Rajagrafindo Persada.

Herawati, T., Krisnatuti, D., Pujihasvuty, R., \& Latifah, E. W. (2020). Faktor-faktor yang memengaruhi pelaksanaan fungsi keluarga. Journal Ilmu Keluarga \& 
Konsumen,13(3), 213-227.

Jailani, M. S. (2014). Teori pendidikan keluarga dan tanggung jawab orang tua dalam pendidikan anak usia dini. Nadwa Jurnal Pendidikan Islam, 8 (2), 246-260

Kemendikbud. (2020). Penyesuaian keputusan bersama empat menteri tentang panduan pembelajaran di masa pandemi covid-19.

Kompas. (2020). Kasus orangtua aniaya anak saat belajar online kembali terekspos.

Labaso', S. (2018). Konsep pendidikan keluarga dalam perspektif Al-Qur’an dan hadis. Jurnal Pendidikan Agama Islam. 15(1). 52-69. https://doi.org/10.14421/jpai.2018.151-04.

Laili, A. N. (2020). Konsep pendidikan informal perspektif Ibnu Sahnun (telaah kitab adab al-muallimin). Indonesia Journal Education Studies. 3 (1), 31-47.

Listyaningsih, L. (2019). Peningkatan prestasi belajar PKN materi sistem pemerintahan indonesia melalui metode contextual teaching and learning bagi siswa kelas VI SD Negeri Combongan. At-Tarbawi: Jurnal Kajian Kependidikan Islam, 4(2), 150. https://doi.org/10.22515/attarbawi.v4i2.1934

Ma'sum, M. A. (2015). Pendidikan luar sekolah (kajian optimalisasi fungsi keluarga sebagai institusi pendidikan). Tafaqquh: Jurnal Penelitian dan Kajian Keislaman, 3(2).23-36.https//doi.org/10.52431/tafaqquh.vi3i245.

Nartiningrum, N., \& Nugroho, A. (2020). Online Learning amidst Global Pandemic: EFL Students' Challenges, Suggestions, and Needed Materials. ENGLISH FRANCA: Academic Journal of English Language and Education, 4(2), 115-140.

Nugroho, A., Haghegh, M., \& Triana, Y. (2021). Emergency Remote Teaching amidst Global Pandemic: Voices of Indonesian EFL Teachers. VELES Voices of English Language Education Society, 5(1), 66-80.

Nugroho, W. (2019). Pengaruh Layanan Mediasi Terhadap Perilaku Bullying. Jurnal Medi Kons, 5(2), 103-114.

Pratiwi, E. W. (2020). Dampak covid-19 terhadap kegiatan pembelajaran online di sebuah perguruan tinggi kristen di Indonesia. Prespektif Pendidikan Islam. 34(1).1-8. https://doi.org/10.21009/PIP.341.1.

Purba, R., Harahap. (2019). Hubungan fungsi afektif keluarga dengan kecerdasan emosional remaja di SMA Negeri 1 kecamatan Panai Hulu kabupaten Labuhan Batu tahun 2019. Jurnal Penelitian keperawatan Medik. 1(2), 5357.https://doi.org/10.366656/jpkm.v1i2.122.

Putria, H. (2020). Analisis proses pembelajaran dalam jaringan (daring) masa pandemi covid-19 pada guru sekolah dasar. Jurnal Basicedu. 4(4), 861-872. ttps://doi.org/10.31004/basicedu.v4i4.460

Salusi, U. (2017). Pelaksanaan fungsi edukatif keluarga yang bekerja (studi kasus: keluarga di Desa Tanah Rekah kecamatan kota Mukomuko Kabupaten Mukomuko).Thesis: Sosiology of Education Studies Program.1-10.

Sudiapermana, E. (2009). Pendidikan Informal Reposisi , Pengakuan dan Penghargaan. Jurnal Pendidikan Luar Sekolah. 4(2).1-7.

Ubabuddin. (2018). Pendidikan keluarga dalam perspektif Islam. Inovatif: Jurnal Penelitian Pendidikan, Agama dan Kebudayaan. 4(2), 76-91.

Wahyuningsih, E.\&Baidi. (2021). Scrutinizing the potential use of discord application as a digital platform amidst emergency remote learning. Journal of Educational Management and Instruction, 1(1), 9-18.

Wijayanti, F. T. (2019). Peran orang tua dalam mengembangkan kecerdasan spiritual anak. Jurnal El-Hamra, 4(2), 73-80.

Yakub. (2020). Pendidikan informal dalam prespektif Pendidikan Islam. Tarbawi. 5(1). 93-103.

Zainuri, A. (2018). Pendidikan karakter di keluarga. Tadrib. 4(2), 260-279.

Zuhlaini. (2019). Peranan keluarga dalam menanamkan nilai-nilai pendidikan Agama Islam kepada anak. Jurnal Al-Hikmah, 1(1), 1-15. 